3. Бойчик І. М., Харів П. С., Хопчпн М. І., Піча Ю. В. Економіка підприємства - К.: "Каравела"; Львів: "Новий світ 2000", 2001. - 298 c

4. Грузинов В. П., Грибов В. Д. Экономика предприятия: Учебное пособие. - М.: Финансы и статистика, 1998.

5. Економіка підприємства: Підручник / За заг. ред. С. Ф. Покропивного - Вид 2-ге. - К.: КНЕУ, 2000.

6. Економіка підприємства. Збірник практичних задачі і конкретних ситуацій: Навч. Посібник. / За ред. С. Ф. Покропивного. - К.: КНЕУ, 1999.

7. Економіка підприємства: Навч. -метод. посібник для самостійного вивчення дисциплін / О. Г. Швиданенко та інші - К.: КНЕУ, 2000.

8. Економіка підприємства: Структурно-логічний навч. посібник/ За ред. С. Ф. Покропивного. - К.: КНЕУ, 2001. - 457 c.

9. Мадзігон В.В. Теорія попиту і пропозиції $\quad$ підприємницькій $\quad$ діяльності $\quad$ в ринкової економіки на товари і послуги. // Молодь і ринок. - 2011. - №2(73). - С. 41 - 46.

10. Мадзігон В.М. Підприємництво: причини виникнення i форми існування, підготовка мол оді до підприємницької діяльності// Актуальні проблеми економіки. - 2010. - №7(109). - С. 3 - 12.

11.Я.О. Орищак М.І. Стебло Основи економіки. м. Тернопіль, 1998р. С - 110.

Рецензент д.е.н., професор Вахович I.M.

УДК 620.9(477):33.021.8

Ліщук B.I., к.е.н., доцент

Східноєвропейський національний університет імені Лесі Українки

Ліщук М.Є., к.с.-г.н., доцент

Московчук А.Т., к.е.н., доцент

Луцький національний технічний університет

\title{
РЕФОРМУВАННЯ РИНКУ ЕЛЕКТРОЕНЕРГІЇ В УКРАЇНІ: СТАН, РИЗИКИ ТА ПЕРСПЕКТИВИ
}

У статті розглянуто проблему реформування електроенергетичного ринку України та перспективи його інтегрування у європейський енергетичний простір. Здійснено аналіз етапів реформування ринків електроенергії країн Свропейського Союзу з точки зору завдань і проблем, що виникали. Охарактеризовано стан реформування ринку в Україні та основні ризики. Окреслено основні заходи, що сприятимуть підвищенню ефективності реформ.

Ключові слова: оптовий ринок електроенергії, балансуючий ринок, внутрішньодобовий ринок, ринок «на добу вперед», ризик, «зелений» тариф, анбандлінг.

Lishchuk V., Lishchuk M., Moskovchuk A.

\section{THE ELECTRICITY MARKET IN UKRAINE REFORMATION: STATE, RISKS AND PERSPECTIVES}

The article deals with the reformation problem of Ukrainian electricity market and the prospects for its integration into the European energy space. The analysis of the stages of reforming the electricity markets of the European Union countries their tasks and problems that have arisen has been analyzed. The state of market reform in Ukraine and the main risks are described. The main measures that will promote the effectiveness of reforms are outlined.

Key words: wholesale electricity market, balancing market, internal market, «day ahead» market, risk, «green» tariff, unbundling.

Лищук В. И., Лищук М. Е., Московчук А. Т.

\section{РЕФОРМИРОВАНИЕ РЫНКУ ЭЛЕКТРОЭНЕРГИИ В УКРАИНЕ: СОСТОЯНИЕ, РИСКИ И ПЕРСПЕКТИВЫ}

В статье рассмотрена проблема реформирования электроэнергетического рынка Украины и перспективы его интегрирования в европейское энергетическое пространство. Осуществлен анализ этапов реформирования рынков электроэнергии стран Европейского Союза с точки зрения задач и проблем, которые возникали. Охарактеризовано состояние реформирования рынка в Украине и основные риски. Определены основные мероприятия, способствующие повышению эффективности реформ. 
Ключевые слова: оптовый рынок электроэнергии, балансирующий рынок, внутрисуточный рынок, рынок «на сутки вперед», риск, «зеленый» тариф, анбандлинг.

Постановка проблеми у загальному вигляді i iї зв'язок 3 важливими науковими та практичними завданнями. Упродовж останніх п'яти років Україна поступово змінює вектор інтегрування національної економіки у напрямі посилення зв'язків 3 європейським економічним простором. Це потребує формування конкурентоспроможної економічної системи, що функціонує у глобальному світі, та реформування у багатьох сферах і видах діяльності.

Процес змін енергетичної галузі, зокрема електроенергетики, має відбуватися прискореними темпами, що обумовлено їі вагомим впливом на соціально-економічний розвиток країни. Стратегія реформування ринку електроенергетики, який характеризується високим рівнем монополізації, передбачає створення умов i можливостей для конкурентного середовища. Це, з одного боку, сприятиме підвищенню ефективності електроенергетичного ринку, а з іншого, призведе до виникнення ризиків $і$ загроз у стабільності й перспективах його функціонування.

Аналіз останніх досліджень, у яких започатковано вирішення проблеми. Дослідженню особливостей моделей електроенергетичного ринку, нормативному забезпеченню, реформуванню світового і національного ринків електроенергетики присвячені праці багатьох вітчизняних та зарубіжних вчених, таких як: Беляєв Л., Казанський С., Кожевніков А., Коссе І., Палійчук У., Пляцко С., Слупський Б., Тукенов А., Хант С., Шаттлворт Г., Щербина Л. та ін. Проте існує потреба комплексної оцінки стану трансформації національного електроенергетичного ринку, ризиків, що виникають, та визначення перспектив розвитку 3 позицій імплементації вимог європейського законодавства та останніх структурних змін в економіці Україні.

Цілі статті. Метою дослідження $\epsilon$ оцінка стану реформування ринку електроенергії в Україні, систематизація ризиків, що виникають в процесі структурних змін та визначення перспектив його розвитку.

Виклад основного матеріалу дослідження 3 повним обгрунтуванням отриманих наукових результатів. Україна інтегрується у європейський ринок електроенергетики, тому досвід країн СС у сфері реформування ринків електроенергії $€$ найбільш важливим та необхідним.

Наприкінці вісімдесятих років XX ст. ЄС поставив за мету створити єдиний, конкурентний та гнучкий енергетичний ринок, який здатний швидко пристосовуватися до змін, що відбувають у зовнішньому та внутрішньому середовищах. До початку реформування європейські країни мали різні умови функціонування енергетичних ринків, проте у більшості з них збігалися цілі: 1) підвищення ефективності діяльності на основі інновацій; 2) зниження цін на електроенергію; 3) залучення інвестицій у електроенергетику.

Процес реформування європейського ринку координувала Європейська Комісія, яка розробила організаційні, правові та технологічні засади, що створили підгрунтя для змін на внутрішніх національних енергетичних ринках щодо їх інтегрування у європейський простір. Лібералізація енергоринків ЄС передбачала створення відповідної нормативно-правової бази і здійснювалась у три етапи. На кожному етапі: 1) формувався енергетичний пакет у вигляді директив, регламентів тощо, що визначають пріоритетні засади змін і 2) узагальнювалися проблеми та недоліки, що виникали в процесі перетворень (рис.1).

Шляхи трансформування електроенергетичного сектору країн відрізняються, проте спільним є те, що відбувається: 1) розмежування природних монополій (передача електроенергії, оперативно-диспетчерське управління) і потенційно конкурентних (генерація, збут) видів діяльності; 2) демонополізація сектору 3 одночасним антимонопольним регулюванням; 3) створення умов недискримінаційного доступу до інфраструктури для незалежних постачальників електроенергії. 
Досвід країн ЄС у реформуванні енергетичної сфери створить необхідну базу для процесів лібералізації енергетичної системи Україні, яка за розмірами є шостою в Свропі після Німеччини, Франції, Італії, Іспанії та Великобританії. До Об'єднаної енергетичної системи (ОЕС) України входять електростанції енергогенеруючих компаній (14 ТЕС, 4 AЕC, 7 ГЕС, 3 ГАЕС), а також 97 ТЕЦ, малі ГЕС, ВЕС, СЕС та інші, магістральні електромережі ДП НЕК «Укренерго», розподільчі електромережі регіональних енергопостачальних компаній.

Загальна динаміка споживання, виробництва та експорту електроенергії в Україні за 2014-2017 pp. є негативною, що обумовлено складною економіко-політичною ситуацією. Так, виробництво електроенергії скоротилось на 20\%, обсяг споживання - на 29 і найбільш негативних змін зазнав експорт електроенергії, обсяги якого скоротились на 71,4\% (лише у 2017 р. відбулось незначне його зростання на 0,4 млрд кВт год, тобто на $11 \%)$ [3].

\begin{tabular}{|c|c|}
\hline & $\begin{array}{l}\text { - Основні завдання: створення механізму щодо підвищення прозорості цін на } \\
\text { електроенергію, гарантія якості і надійності забезпечення споживачів СС } \\
\text { електроенергією, гармонізація національних правил транзиту та технічних } \\
\text { правил роботи систем, вільний доступ учасників і створення конкурентних } \\
\text { ринків. } \\
\text {-Основні проблеми: зловживання монопольним становищем з боку потужних } \\
\text { компаній, не повністю були вирішені питання запровадження справедливих } \\
\text { тарифів і захисту прав невеликих споживачів. }\end{array}$ \\
\hline & $\begin{array}{l}\text { - Основні завдання: затвердження правил фінансового обліку за видами } \\
\text { діяльності монополістів та механізм створення конкурентного середовища у } \\
\text { роздрібних та оптових поставках електроенергії, юридичне розділення } \\
\text { операторів мереж передавання електроенергії та тих, які займаються } \\
\text { продажем електроенергії кінцевим споживачам, створення регулюючого } \\
\text { органу на національному рівні. } \\
\text { - Основні проблеми: збереження високого рівня монополізації ринку } \\
\text { електроенергетики більшості країн СС, недостане інтегрування між } \\
\text { національними ринками, відсутність прозорості функціонування сфери } \\
\text { енергетики. }\end{array}$ \\
\hline & $\begin{array}{l}\text {-Основні завдання: виокремлення діяльності, пов’язаної з транспортуванням } \\
\text { електроенергії від інших видів діяльності, визначення єдиного рівня тарифів } \\
\text { за використання енергетичних ресурсів на всій території ЄС, регулювання } \\
\text { доступу та приєднання до єдиної системи третіх осіб. } \\
\text { - Основні проблеми: недостатність економічних стимулів для підвищення } \\
\text { ефективності діяльності, зниження обсягів фінансування для будівництва } \\
\text { капіталомістких енергооб'єктів, виникнення дефіциту генеруючих } \\
\text { потужностей, зниження надійності роботи енергосистеми, несвоєчасність } \\
\text { цінових сигналів і недосконалість відповідних механізмів для інвестування в } \\
\text { нові генерувальні і мережеві потужності. }\end{array}$ \\
\hline
\end{tabular}

Рис. 1. Основні завдання і проблеми реформування електроенергетичних ринків СС Джерело: складено за $[1,2]$

Важливий вплив на динаміку електроенергетичного ринку має структура споживання: 1) найбільша питома вага у споживанні електроенергії припадає на промисловість і населення (відповідно понад 40 і 30\%), частка споживання в інших видах діяльності $\epsilon$ відносно невисокою і коливається від 0,7 (будівництво) до 13\% (комунально-побутові споживачі); 2) деяке пожвавлення економіки i, зокрема промисловості, призвело до збільшення споживання електроенергії у 2017 році на 2,2\%. Активізація будівельної галузі в останні кілька років була стимулятором споживання електроенергії у будівництві на $10,5 \%$ і у виробництві будівельних матеріалів - на 7\% [4]. 
Підвищення ефективності функціонування ринку електроенергетики України визначається сукупністю факторів. Важливим фактором, що створить передумови для позитивних зрушень $є$ зниження рівня монополізації та лібералізація різних сегментів ринку.

Від 1996 року в Україні функціонує Оптовий ринок електричної енергії (OPE), на якому здійснюються операції купівлі-продажу. Він був створений за зразком моделі пулу електроенергії Англії та Уельсу «єдиний покупець». На ринку є такі суб'єкти як природні монополії (оператор магістральних мереж - НЕК «Укренерго»). Проте у виробничій сфері та секторі постачання електроенергії деякі учасники ринку функціонують на засадах відносної конкуренції. Така форма ОРЕ в Україні, в якій зберігається високий ступень монополізму, була необхідним кроком, тому що енергетичний сектор країни характеризувався нестабільністю зі зростанням неплатежів та заборгованості за поставлену електроенергію. Так, до 1999 року переважали різні форми бартерних розрахунків, і лише близько 6\% оплати здійснювалось грошима [5].

Сучасні тенденції розвитку електроенергетичної галузі, проблеми, що накопичилися, вимагали переходу від ринку «єдиного покупця» до більш ефективної i орієнтованої на потреби споживачів моделі ринку електроенергії - двосторонніх контрактів з балансуючим ринком.

В останні роки прискорився процес кардинального реформування діяльності на ринку електроенергетики в Україні. Важливою передумовою організаційно-економічних змін $є$ Закон України «Про ринок електричної енергії», прийнятий у 2017 р., який створює законодавче підгрунтя для реформування. Передбачено, що новий ринок почне функціонувати від 2019 р. - для промислових і від 2020 р. - для непромислових споживачів. Закон [6]: 1) визначає правові та організаційно-економічні засади функціонування ринку; 2) пропонує різні механізми купівлі-продажу електричної енергії через двосторонні договори, ринок «на добу вперед», внутрішньодобовий ринок; 3) врегульовує проблеми балансування в реальному часі обсягів виробництва, імпорту, споживання та експорту електричної енергії через балансуючий ринок та ринок допоміжних послуг; 4) розподіляє компанії на ті, що генерують електроенергію, транспортують і продають безпосередньо споживачу. Основна функція генеруючих компаній - виробництво електроенергії, компаній із розподілу - експлуатація електричних мереж, передача електричної енергії до кінцевого споживача та приєднання нових споживачів і компаній-постачальників - безпосередня робота зі споживачами (укладання договорів, поставка електричної енергії та контроль за розрахунками).

Трансформація електроенергетичної системи України здійснюється шляхом переходу на ринкові відносини, лібералізація її сегментів, укладання прямих договорів, вдосконалення цінової політики й забезпечення надійного постачання, оплати придбаної електроенергії. Однак, створення відносно конкурентного середовища передбачає взаємодію різних суб’єктів, які приймають рішення, проте мають різні інтереси.

Збільшення кількості суб'єктів будь-якого ринку, їх взаємодія та неспівпадання інтересів $є$ джерелом виникнення ризикових ситуацій, оскільки невиконання учасником своїх зобов'язань може призвести до форс-мажорних обставин.

Суб'єкти ринку електричної енергії, діяльність яких може спричинити ризик, відображені на рис. 2. 

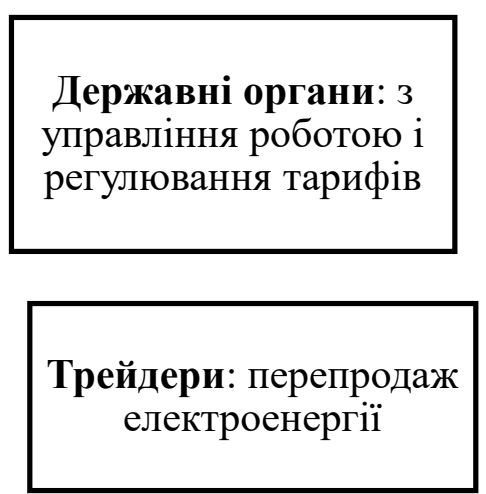
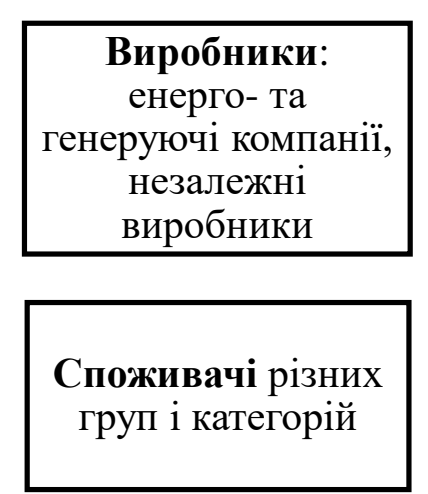

\section{Постачальники:}

компанії 3

транспортування,

розподілу та збуту, компанії-дистриб'ютори

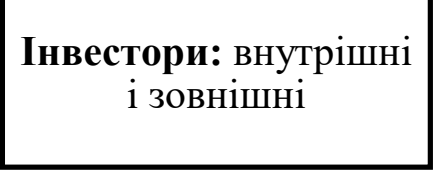

Рис. 2. Суб'єкти ринку електроенергії, що спричиняють ризик

Джерело: складено авторами

Досвід іноземних держав та аналіз початку лібералізації національного ринку електроенергії дозволяє виокремити основні ризики, що можуть виникати в процесі взаємодії суб'єктів ринкових відносин:

1) викривлення ідеї конкурентної моделі ринку і неможливість послаблення впливу монополістів;

2) підвищення тарифів на електроенергію;

3) сторонній (політичний і бізнесовий) вплив на регулювання ринку;

4) виникнення дисбалансу в єдиній енергетичній системі;

5) недостатній обсяг інвестування в розвиток ринку електроенергії.

1. Викривлення ідеї конкурентної моделі ринку і неможливість послаблення впливу монополістів. Закон України «Про ринок електричної енергії» враховує вимоги Третього енергетичного пакета, відповідно до якого Обленерго мають відокремити свою діяльність 3 розподілу і постачання електричної енергії. Це означає створення двох компаній: 1) оператор системи розподілу, що забезпечує експлуатацію, технічне обслуговування й розвиток системи розподілу та здійснює розподіл електроенергії; 2) оператор системи передачі, що постачає (продає) електроенергію споживачам, користуючись мережами операторів системи розподілу.

Варто зазначити, що:

- закон безпосередньо не вирішує питання демонополізації, тому що чинне законодавство формально не вважає існуючих суб'єктів монополістами (це визнано Антимонопольним комітетом України);

- в теперішніх умовах відносної ізольованості енергосистеми України може зберігатися контроль монополістів над ціноутворенням, тому необхідно реально інтегрувати ринок у Європейський простір. Це дасть можливість врахувати інтереси споживача (оскільки ринок передбачає відсутність пріоритетів внутрішнього виробництва перед імпортом), тому що потенційна конкуренція 3 боку імпортної електроенергії буде обмежувати монопольний вплив внутрішніх виробників на ціну;

- новостворені постачальники електроенергії можуть перетворитися у «заступників» Обленерго й зберегти монопольний вплив на споживачів та обмежувати їх вільний вибір. Так, від 2019 р. у Луцьку оператором системи розподілу електроенергії $\epsilon$ Волиньобленерго, а постачальником - ТОВ «Волиньелектрозбут» (у статутному капіталі 100\% належить Волиньобленерго). Це означає, що формально розподіл відбувся, а реально конкуренція відсутня.

2. Підвищення тарифів на електроенергію. НКРЕКП здійснює регулювання тарифів для всіх постачальників, крім постачальників 3 нерегульованими тарифами. Останні постачають електроенергію непобутовим споживачам на конкурентних засадах за договірними цінами. 
Тариф на електроенергію в Україні один із найнижчих у Європі, проте середня зарплата - також найнижча: якщо в Україні споживач із тарифом 1,68 грн/кВт год витрачає на електроенергію 3,43\% місячної зарплати, то споживач Данії з тарифом 9,51 грн/кВт год витрачає удвічі менше - 1,47\% від зарплати [7].

На теперішній час тарифи на електроенергію, за якими обленерго закуповують іï у ДП «Енергоринок», установлюються НКРЕКП за принципом «Витрати +», що не стимулює зниження неефективних витрат, оскільки обсяг прибутку за методикою «витрати плюс» фактично мало залежить від ефективності роботи підприємства.

Однією з передумов інтеграції енергетичного сектору України до енергетичних ринків $\mathrm{CC} є$ запровадження ринкових підходів до тарифного регулювання природних монополій, які базуються на застосуванні концепцій норми прибутку на інвестований капітал та регуляторної бази активів, впровадженні механізмів багаторічного стимулюючого регулювання із застосуванням методів порівняльного аналізу ефективності компаній (бенчмаркінгу) та врахуванні показників якості послуг [7].

Кабмін України підтримує метод стимулюючого тарифоутворення, проте вважає, що варіант, який був прийнятий НКРЕКП 27.07.2017 p., може призвести до необгрунтованого підвищення тарифів для промисловості. Це, як наслідок, підвищить ціни на товари та послуги, що купують споживачі.

Вважається, що у перехідний період, тарифи для населення будуть зростати. Причиною тому може бути: 1) недооцінка вартості активів ДП «НЕК «Укренерго», результатом якого має стати різке підвищення амортизаційних відрахувань, внаслідок чого має зрости тариф на передачу електроенергії; 2) НКРЕКП прийняла рішення про виключення перехресного субсидіювання, обсяг якого становить 45,8 млрд грн [8]. Це зрівняє тарифи промисловості і населення та призведе до підвищення останніх; 3) 3 середини 2019 р. планується створення енергобірж, що згідно оцінок потребує 500 млн євро і може бути чинником чергового підвищення цін. Аналогічна реформа в Свропі призвела до зростання цін на 30-70\%; 4) у низькоконкурентному середовищі через «змову» виробників ціна електроенергії може бути штучно завищена. Так, близько 54 \% всього ринку - це державний Енергоатом, понад $6 \%$ - державне Укргідроенерго та до $25 \%$ - теплова (більш дорога) генерація приватного ДТЕК, який завдяки рішенням НКРЕКП отримує надприбутки [9].

3. Сторонній (політичний і бізнесовий) вплив на регулювання ринку. Важливим є те, що чинне законодавство не передбачає зміни форми власності для системного оператора (державна форма власності), процес ціноутворення на послуги якого контролюється ззовні. Так, оплата послуг з централізованого диспетчерського управління здійснюється за тарифом, який регулюється НКРЕКП. Враховуючи «вразливість» регулюючого органу до політичних та лобістських бізнесових впливів, економічна обгрунтованість встановлених тарифів може виявитися сумнівною [10].

Сама НКРЕКП $є$ не захищеною від політичного впливу на їі діяльність, тому рівень тарифів може бути необгрунтованим. Прикладом стороннього впливу на тарифоутворення можуть слугувати останні рішення прем'єр-міністра і голови «Нафтогаз» України щодо зниження тарифів на газ. Основним аргументом зниження тарифів можна вважати лише «політичну доцільність». Крім того, це призведе до підвищення ціни газу для підприємств і як наслідок зросте обсяг перехресного субсидіювання.

Крім того, НКРЕКП запроваджує інститут спеціальних рахунків для підприємств, тобто вони не зможуть керувати спецрахунками. Це може бути механізмом для зловживань з боку чиновників.

4. Виникнення дисбалансу в єдиній енергетичній системі. На ринку електроенергії $\epsilon$ важливі обов'язки усіх учасників щодо балансу. Кожен виробник чи постачальник має відповідати за власний небаланс (відхилення від графіку виробництва або споживання). Укладаючи двосторонні контракти або купуючи електроенергію на ринку на добу 
наперед, постачальники і виробники зобов'язуються забезпечити своє споживання та виробництво в певні години на відповідному рівні.

Однак практично забезпечити стовідсоткову відповідність контрактам не реально (погіршення погодних умови може спричинити зростання попиту на електроенергію у споживачів в реальному часі; зміна фактичного обсягу генерації вітровими чи сонячними електростанціями; поламка генеруючого обладнання тощо). Тому відповідальним за баланс ОЕС України загалом в режсиі реального часу буде оператор системи передачі - ДП «НЕК «Укренерго». Він повинен мати відповідні резерви, інструментом створення яких є ринок допоміжних послуг. Такі послуги здійснюються на платній основі, розмір має бути врегульованим вторинним законодавством [10].

5. Недостатній обсяг інвестування в розвиток ринку електроенергії. В Україні середній термін експлуатації розподільчих електромереж перевищує 40 років і інфраструктура зношена на 60-85\%, що призводить до виникнення проблем із забезпеченням безперебійного постачання електроенергії споживачам. За останні п’ять років у вітчизняні обленерго було вкладено лише 14 млрд грн, тоді як за планом передбачалось 68 млрд грн. За оцінкою «Асоціації операторів розподільчих електромереж України» для забезпечення надійної i безперебійної поставки електроенергії на модернізацію електромереж у найближчі 10 років необхідно близько \$25 млрд [10]. Такий обсяг інвестицій можна забезпечити шляхом проведення прозорих приватизаційних конкурсів, що дозволить залучити іноземний капітал 3 новими технологіями, високою якістю менеджменту тощо.

Висновки. Отже, аналіз зарубіжного досвіду, стану трансформування електроенергетичного ринку України та ризиків, що можуть виникнути, дозволяє визначити перспективи його інтегрування у європейський ринок. Вони залежать від ефективності реформування ринку, для підвищення якої необхідно: 1) для здешевлення електроенергії для суспільно важливих споживачів (шкіл, лікарень тощо) стимулювати використання альтернативних джерел енергії через «зелений» тариф, який буде важелем перетворення ринку у більш конкурентний; 2) забезпечити прозорість ринку з точки зору надання відкритої та об'єктивної інформації для всіх зацікавлених суб'єктів (населення, промислових споживачів) щодо формування тарифів на електроенергію; 3) убезпечити НКРЕКП від можливого впливу на їі діяльність сторонніх зацікавлених осіб; 4) з метою вільного ціноутворення синхронізувати реформування оптового та роздрібного ринків; 5) проведення неформального, ефективного анбандлінгу; 6) розвивати мікромережі, що поєднують виробництво та споживання електроенергії в декількох населених пунктах, зокрема ті, що використовують альтернативні джерела. Це дозволить забезпечити енергією віддалені райони без підтримки дорогих централізованих мереж; 7) реалізовувати послідовну політику у напрямі залучення інвестицій (зокрема іноземних) для оновлення основних засобів галузі та підвищення рівня конкуренції; 8) здійснювати якісну комунікацію зі споживачами і забезпечити активну участь громадянського суспільства в обговоренні реформ.

\section{Список використаних джерел:}

1.Огляд діяльності реформованих ринків електроенергії та тенденції ціноутворення на ринках електроенергії країн OЕСР та Європейського Союзу. URL : https://ua.energy/wp-content/uploads/2018/01/6.-Rynky-elektroenergiyi.pdf.

2.Слупський Б. Основні моделі ринків електроенергетики та особливості їх державного регулювання: порівняльний аналіз. URL : http://www.dridu.dp.ua/vidavnictvo/2009/2009-03(3)/09sbvrpa.pdf.

3.Статистический ежегодник мировой энергетики 2018. URL : https://yearbook.enerdata.ru

4.Офіційний сайт Міністерства енергетики та вугільної промисловості України. Режим доступу http://mpe.kmu.gov.ua/.

5.Модель енергоринку України. URL: http://www.ukrenergoexport.com/uk/content/.

6.Закон України «Про ринок електричної енергії». URL: https://zakon.rada.gov.ua/laws/show/2019-19.

7.Аналіз тарифо- та ціноутворення на електроенергію в країнах ЄС та ОЕСР. Системи стимулюючого тарифоутворення. URL : https://ua.energy/wp-content/uploads/2018/10/3.-Taryfo_tsinoutv_elektroen.pdf.

8.Оржель О. Новий ринок електроенергіï. Пересічний споживач платитиме більше. URL: https://delo.ua/business/novijrinok-elektroenergiji-peresichnij-spozhivach-platitime-bil-330368/.

9.Беззуб I. Чи запрацюе в Україні ринок електричної енергіï? URL: http://www.nbuviap.gov.ua/index.php?option=com_content\&view=article\&id=3781 :chi-zapratsyue-v-ukrajini-rinokelektrichnoji-energiji\&catid=8\&Itemid $=350$.

10. Ущаповський К. В. Вплив реформування ринку електроенергії України на діяльність ДП «НЕК «Укренерго» URL : https://periodicals.karazin.ua/economy/article/view/5390. 